\title{
A survey of the functional, gut digestive, and serum antioxidant factors in Salmo trutta caspius (Kessler) fingerlings with the application of a dietary synbiotic
}

\author{
Maryam Aftabgard, Alireza Salarzadeh, Mahmoud Mohseni, Amir Houshang Bahri \\ Shabanipour, Mohammad Ebrahim Jalil Zorriehzahra
}

Received - 19 April 2017/Accepted - 05 December 2017. Published online: 31 March 2018; Inland Fisheries Institute in Olsztyn, Poland Citation: Aftabgard M., Salarzadeh A., Mohseni M., Shabanipour A.H.B., Zorriehzahra M.E.J. 2018 - A survey of the functional, gut digestive, and serum antioxidant factors in Salmo trutta caspius (Kessler) fingerlings with the application of a dietary synbiotic - Fish. Aquat. Life 26: 31-38.

\begin{abstract}
This study evaluated the effectiveness of BetaPlus ${ }^{\circledR}$ combined with isomalto-oligosaccharide (IMO) in Caspian brown trout, Salmo trutta caspius (Kessler), fingerlings. A total of 120 Caspian brown trout $(8.75 \pm 0.03 \mathrm{~g})$ were fed in two treatments, including the control diet and the synbiotic $\operatorname{diet}\left(0.1 \%\right.$ BetaPlus ${ }^{\circledR}+0.2 \%$ IMO) in three replicates per treatment for seven weeks. The growth indices (final weight, weight gain, average daily growth, specific growth rate, feed efficiency, and protein efficiency ratio) exhibited significant improvement in the fish fed the synbiotic $\operatorname{diet}(\mathrm{P}<0.05)$. The highest ash crude protein, and crude fiber, as well as the lowest crude lipid, dry matter, and carbohydrate detected in the carcass of fish treated with the synbiotic were significant
\end{abstract}

\footnotetext{
M. Aftabgard [ $\Xi^{\circ}$ ], A. Salarzadeh, A.H. Bahri Shabanipour Department of Fisheries, College of Natural Resources, Bandar Abbas Branch, Islamic Azad University, P.O. Box: 79159-1311, Bandar Abbas, Iran

\section{Mohseni}

Coldwater Fishes Research Center (CFRC), Iranian Fisheries Science Research Institute (IFSRI), Agricultural Research, Education and Extension Organization (AREEO), P.O.Box: 46815-467, Tonekabon, Iran

M.E.J. Zorriehzahra

Department of Aquatic Animal Health and Diseases, Iranian Fisheries Science Research Institute (IFSRI), Agricultural Research, Education and Extension Organization (AREEO), P.O. Box: 15745-133, Tehran, Iran
}

$(\mathrm{P}<0.05)$. In addition, the fish fed the synbiotic diet showed significantly higher gut trypsin activity and trypsin:chymotrypsin ratio, as well as serum superoxide dismutase activity $(\mathrm{P}<0.05)$. Thus, BetaPlus ${ }^{\circledR}$ in combination with IMO can effectively lead to a considerable increase in functional factors, as well as gut proteases and serum antioxidant indicators in S. trutta caspius fingerlings.

Keywords: antioxidant defense, carcass, Caspian brown trout, growth performance, proteases, synbiotic

\section{Introduction}

The Caspian brown trout (Salmo trutta caspius Kessler) (family: Salmonidea) is one of the nine brown trout (Salmo trutta) subspecies with the highest weight, size, and growth rate, and it is one of the most important endemic species of the Caspian Sea southern coast (Dorafshan et al. 2008). During two past decades, natural stocks of this valuable anadromous species have increasingly decreased due to human activities, including overfishing, habitat pollution, and environment alterations (Sotoudeh et al. 2011). According to the International Union for Conservation of Nature (IUCN) criteria, the Caspian 
brown trout is critically endangered in the Caspian sea southern coast (Coad 2000). Therefore, this very vulnerable species is under protection of the Iranian Fisheries Organization (IFO).

Over the past two decades, aquaculturists have used antibiotics widely to improve growth performance, feed efficiency, immune stimulation, and the survival rate of aquatic animals against environmental stress and diseases. Because of the accumulation of antibiotic residues and increasing pathogen resistance in different animals (Ramos et al. 2013), there is currently worldwide consideration of using alternative feed supplements such as biotic components like probiotics, prebiotics, and synbiotics in aquatic production. As defined by Ringø et al. (2010), probiotics are live microorganisms added to feed or rearing water that when administered to fish in adequate amounts confer increase in viability, enhance immune and digestive systems, promote growth and general welfare. According to the definition of Gibson and Roberfroid (1995), prebiotics are as non-digestible food ingredient that beneficially affects the host by selectively stimulating the growth and/or activity of one or a limited number of bacteria in the colon, and thus improves host health. It is well documented that the addition of prebiotics to probiotics compounds as synbiotics thanks to the synergistic effects that can result in probiotic bacteria survival and growth enhancement (Adebola et al. 2014).

BetaPlus ${ }^{\circledR}$, the commercial probiotic used in this research, is a two-species Bacillus probiotic that includes Bacillus subtilis and B. licheniformis. Isomalto-oligosaccharide (IMO), which was the prebiotic applied in our study, is also called a bifidus-factor because of its augmentation of gut acid lactic bacteria, or bifidobacteria (Ringø et al. 2010). Furthermore, Kaneko et al. (1995) state that IMO is mainly composed of isomaltose, isomaltotriose, panose, isomaltotetraose, etc. Several studies demonstrated that different synbiotic compounds can enhance growth, immunity, and antioxidant defense in fish species (Zhang et al. 2013, 2015, Van Doan et al. 2016, Hoseinifar et al. 2017). This study was preliminary designed to evaluate the efficiency of a dietary synbiotic (BetaPlus ${ }^{\circledR}+\mathrm{IMO}$ ) on growth enhancement, carcass alteration, antioxidant defense, and gut digestive enzymes in S. trutta caspius fingerlings.

\section{Material and method}

\section{Fish and trial condition}

At the start of the trial, 120 Caspian brown trout, Salmo trutta caspius fingerlings $(8.75 \pm 0.03 \mathrm{~g})$ were stocked into six polypropylene tanks (300 l) (20 fish per tank) at the health and disease section of the Coldwater Fish Research Center (CFRC) (Dohezar, Tonekabon, Mazandaran, Iran). For acclimation to experimental conditions, the fish were fed a commercial extruded diet for two weeks. The water in each tank was continuously aerated through air stones. The trial was performed in a flow-through system in a 12:12 h light:dark cycle. Based on the previously published study by Aftabgard et al. (2017), the Caspian brown trout fingerlings were fed the trial diets manually to apparent satiation two times a day for seven weeks in two trial groups, including a control group and a synbiotic group $\left(0.1 \%\right.$ BetaPlus ${ }^{\circledR}+0.2 \%$ IMO) with three replicates per group.

\section{Feed preparation}

In this study, a commercial extruded diet (basal or control diet) containing 46\% crude protein, 14\% crude lipid, $3 \%$ crude fiber, $10 \%$ ash, $11 \%$ moisture, and $1.5 \%$ phosphorous was purchased from Faradaneh Co. (Iran). BetaPlus ${ }^{\circledR}$ is a commercial probiotic containing two bacteria strains in spore form $\left(5.12 \times 10^{12} \mathrm{CFU} \mathrm{kg}^{-1}\right.$ of each strain) of $B$. subtilis (DSM 5750) (obtained by soya bean fermentation) and B. licheniformis (DSM 5749) (isolated from soil) that was purchased from the Biochem Co. (Germany). The prebiotic IMO (Serva Feinbiochemica Co., Heidelberg/New York) was obtained from chicory. To prepare the synbiotic diet, BetaPlus ${ }^{\circledR}$ at $0.1 \%$ and IMO at $0.2 \%$ of the basal diet 
were blended, dissolved in sterile distilled water (100 mL per $1 \mathrm{~kg}$ of diet) (Adel et al. 2017), and then sprayed on the extruded feed. The control diet was sprayed with sterile distilled water only. Then, according to the Aftabgard et al. (2017) study, the trial diets were air-dried and stored until use. The trial diets were then air-dried for $4 \mathrm{~h}$ and stored at $4^{\circ} \mathrm{C}$ until use. In order to maintain the quality of the food, the trial diets were prepared twice weekly.

\section{Growth and carcass indices assay}

At the end of seven weeks and after $24 \mathrm{~h}$ fasting, the Caspian brown trout in two trial treatments were randomly sampled, and anesthetized with clove powder at $200 \mathrm{mg} \mathrm{L}^{-1}$. Thus, four fish per replicate (12 fish per treatment) were weighed individually. The following formulas were used to calculate the growth parameters:

- weight gain, $\mathrm{WG},\left(\mathrm{g} \mathrm{fish}^{-1}\right)=$ final body weight (g) - initial body weight ( $\mathrm{g}$ );

- daily growth rate, DGR $\left(\mathrm{g} \mathrm{d}^{-1}\right)=$ (final body weight $(\mathrm{g})$ - initial body weight $(\mathrm{g})) \times$ rearing period $^{-1}$ (days);

- specific growth rate, SGR $\left(\% \mathrm{~d}^{-1}\right)=100 \times(\ln$ final body weight $(\mathrm{g})-\ln$ initial body weight (g) $\times$ rearing period $^{-1}$ (days);

- feed efficiency, FE $(\%)=($ wet weight gain $(\mathrm{g}) \times$ dry feed intake $\left.{ }^{-1}(\mathrm{~g})\right) \times 100$

- protein efficiency ratio, PER $=($ final fish weight (g) - initial fish weight $(\mathrm{g})) \times$ quantity of protein $\mathrm{fed}^{-1}(\mathrm{~g})$.

After measuring the final weight, carcass analysis of the four fish per triplicate was performed in accordance with the AOAC (1990). Crude protein content was assessed with the Kjeldahl method. Crude lipid was analyzed using the Soxhlet method. Crude fiber was measured using an automatic analyzer. Ash content was determined with cremate in an electric oven at $550^{\circ} \mathrm{C}$ for $4 \mathrm{~h}$. Dry matter was estimated gravimetrically after drying the samples at $105^{\circ} \mathrm{C}$ for $24 \mathrm{~h}$. Carbohydrate content was determined according to the Gouveia and Davies (2000) method.

\section{Blood sampling and serum antioxidant enzyme assay}

To evaluate the serum antioxidant enzymes, blood samples were collected from five Caspian brown trout per replicate anesthetized with $200 \mathrm{mg} \mathrm{L}^{-1}$ clove powder by cutting of the caudal vein and pooling the blood into Eppendorf tubes. Serum samples were obtained using standard methods, and kept at $-20^{\circ} \mathrm{C}$ until analysis. To measure the serum superoxide dismutase (SOD) activity, the pyrogallol auto-oxidation reaction in the presence of hydrogen peroxide $\left(\mathrm{H}_{2} \mathrm{O}_{2}\right)$ was investigated. Thus, SOD activity decreased to inhibit pyrogallol auto-oxidation and was measured based on the decrease in light absorption with a spectrophotometer at $420 \mathrm{~nm}$ (Marklund and Marklund 1974). To assess the catalase activity (CAT), the serum samples were placed in the presence of an $\mathrm{H}_{2} \mathrm{O}_{2}$ solution for 10 minutes (at room temperature). An ammonium molybdate solution was used to stop the oxidation process. Because of the reaction of ammonium molybdate and $\mathrm{H}_{2} \mathrm{O}_{2}$, a yellow compound was formed. Thus, CAT activity was determined based on the absorption of the yellow colour at $410 \mathrm{~nm}$ with a spectrophotometer against the control (blank) (distilled water was used as the blank) (Goth 1991).

\section{Gut digestive enzymes activity assay}

To determine the activities of digestive enzymes, intestinal tissue samples were collected from three Caspian brown trout under $24 \mathrm{~h}$ food interruption per tank. At first, according to Guzmán-Villanueva et al. (2014), intestinal samples were weighed separately and homogenized in four volumes of cold distilled water $\left(4^{\circ} \mathrm{C}\right)$. Then, the suspensions were centrifuged at $12000 \mathrm{~g}$ for $10 \mathrm{~min}$ at $4^{\circ} \mathrm{C}$, and stored at $-80^{\circ} \mathrm{C}$ until enzymatic analysis. The amylase activity was determined based on the method described by Bernfeld (1955), using starch as the substrate. The lipase activity was measured according to the Yanbo and Zirong (2006) protocol by evaluating the fatty acids produced by the hydrolysis process of triglycerides in a stabilized emulsion of olive oil. The trypsin activity 
was assayed according to the method described by Erlanger et al. (1961) using N-a-benzoyl-DL-arginine 4-nitroanilide hydrochloride (BAPNA) as a substrate in $10 \mathrm{mM}$ dimethyl sulfoxide (DMSO) and a 50-mM Tris- $\mathrm{HCl}$ buffer with $10 \mathrm{mM} \mathrm{CaCl} 2$ at $\mathrm{pH} 8.2$. Chymotrypsin activity was assayed according to the procedure explained by Del Mar et al. (1979) using N-succinyl-Ala-Ala-Pro-Phe-p-nitroanilide (SAAPNA) as the substrate in $10 \mathrm{mM}$ DMSO and $100 \mathrm{mM}$ Tris- $\mathrm{HCl}$ buffer with $10 \mathrm{mM} \mathrm{CaCl}_{2}$ at $\mathrm{pH}$ 7.8. According to Bradford (1976), the supernatant soluble protein content was estimated using bovine albumin as the standard solution. The digestive enzyme activity in the current trail was expressed as $\mathrm{U} \mathrm{mg}^{-1}$ protein $\mathrm{min}^{-1}$. The above enzymatic analysis was conducted at $25^{\circ} \mathrm{C}$ in triplicate.

\section{Statistical analysis}

The variance homogeneity of all the data was first checked with the Kolmogorov-Smirnov test and then exposed to independent sample $t$-tests to compare two treatments via SPSS 23.0 (SPSS Inc., Chicago, IL, USA). The average values were significant by $\mathrm{P}<$ 0.05. The data for all the assays are also presented as average values \pm standard error of the mean (SEM).

\section{Results}

After seven weeks of the feeding trial, the growth parameters (final weight (FW), WG, DGR, SGR, FE and PER) of fish fed the BetaPlus ${ }^{\circledR}+$ IMO diet were significantly higher than those of the fish fed the control diet $(\mathrm{P}<0.05$; Table 1$)$. The carcass crude protein, ash, and crude fiber were significantly higher in the fish fed the BetaPlus ${ }^{\circledR}+\mathrm{IMO}$ diet than the control group $(\mathrm{P}<0.05)$, while the other carcass items such as crude lipid, dry matter, and carbohydrate were significantly lower in the fish fed the synbiotic diet than in the fish fed the control diet $(\mathrm{P}<0.05$; Table 2$)$. The effects of the

Table 1

Growth factors of Caspian brown trout fingerlings fed the trial diets for seven weeks

\begin{tabular}{lll}
\hline \hline & \multicolumn{2}{l}{ Treatments } \\
\cline { 2 - 3 } Parameters & Control & BetaPlus ${ }^{\circledR}+$ IMO \\
\hline \hline Final weight $(\mathrm{g})$ & $16.32 \pm 0.73^{\mathrm{b}}$ & $18.67 \pm 0.24^{\mathrm{a}}$ \\
Weight gain $\left(\mathrm{g} \mathrm{fish}^{-1}\right)$ & $8.19 \pm 0.97^{\mathrm{b}}$ & $10.57 \pm 0.45^{\mathrm{a}}$ \\
Specific growth rate $\left(\%\right.$ day $\left.^{-1}\right)$ & $1.28 \pm 0.11^{\mathrm{b}}$ & $1.58 \pm 0.05^{\mathrm{a}}$ \\
Daily growth rate $\left(\mathrm{g} \mathrm{day}^{-1}\right)$ & $0.17 \pm 0.02^{\mathrm{b}}$ & $0.22 \pm 0.01^{\mathrm{a}}$ \\
Protein efficiency ratio & $1.51 \pm 0.31^{\mathrm{b}}$ & $2.25 \pm 0.07^{\mathrm{a}}$ \\
Feed efficiency $(\%)$ & $66.33 \pm 13.57^{\mathrm{b}}$ & $98.67 \pm 3.18^{\mathrm{a}}$ \\
\hline \hline
\end{tabular}

Values (mean \pm SEM) in each row with different superscript notations indicate statistically significant differences between the treatments $(\mathrm{P}<0.05)$

Table 2

Carcass composition of Caspian brown trout fingerlings fed the trial diets for seven weeks

\begin{tabular}{lll}
\hline \hline & \multicolumn{2}{l}{ Treatments } \\
\cline { 2 - 3 } Parameters & Control & BetaPlus ${ }^{\circledR}+$ IMO \\
\hline \hline Crude protein (\%) & $54.96 \pm 0.48^{\mathrm{b}}$ & $62.91 \pm 0.15^{\mathrm{a}}$ \\
Crude lipid (\%) & $26.05 \pm 0.21^{\mathrm{a}}$ & $21.02 \pm 0.65^{\mathrm{b}}$ \\
Crude fiber (\%) & $0.33 \pm 0.03^{\mathrm{b}}$ & $0.60 \pm 0.02^{\mathrm{a}}$ \\
Ash (\%) & $6.89 \pm 0.02^{\mathrm{b}}$ & $8.04 \pm 0.10^{\mathrm{a}}$ \\
Dry matter (\%) & $29.13 \pm 0.35^{\mathrm{a}}$ & $26.96 \pm 0.44^{\mathrm{b}}$ \\
Carbohydrate (\%) & $10.64 \pm 0.46^{\mathrm{a}}$ & $6.86 \pm 0.21^{\mathrm{b}}$ \\
\hline \hline
\end{tabular}

Values (mean \pm SEM) in each row with different superscript notation indicate statistically significant differences between the treatments $(\mathrm{P}<0.05)$ 
Table 3

Serum antioxidant enzyme activity of Caspian brown trout fingerlings fed the trial diets for seven weeks

\begin{tabular}{lll}
\hline \hline & Treatments & \\
\cline { 2 - 3 } Parameters & Control & BetaPlus ${ }^{\circledR}+$ IMO \\
\hline \hline SOD $\left(\mu \mathrm{ml}^{-1}\right)$ & $52.00 \pm 4.73^{\mathrm{b}}$ & $72.67 \pm 5.90^{\mathrm{a}}$ \\
CAT $\left(\mu \mathrm{ml}^{-1}\right)$ & $4.37 \pm 0.12^{\mathrm{a}}$ & $4.07 \pm 0.09^{\mathrm{a}}$ \\
\hline \hline
\end{tabular}

Values (mean \pm SEM) in each row with different superscript notation indicate statistically significant differences between the treatments $(\mathrm{P}<0.05)$

Table 4

Digestive enzyme activity and soluble protein concentration in the gut of Caspian brown trout fingerlings fed the trial diets for seven weeks

\begin{tabular}{lll}
\hline \hline & Treatments & \\
\cline { 2 - 3 } Parameters & Control & BetaPlus ${ }^{\circledR}+$ IMO \\
\hline \hline Soluble protein $\left(\mathrm{mg} \mathrm{ml}^{-1}\right)$ & $1.86 \pm 0.29^{\mathrm{a}}$ & $2.42 \pm 0.11^{\mathrm{a}}$ \\
Amylase $\left(\mathrm{U} \mathrm{mg}^{-1}\right.$ protein) & $43.51 \pm 12.24^{\mathrm{a}}$ & $49.10 \pm 9.25^{\mathrm{a}}$ \\
Lipase $\left(\mathrm{U} \mathrm{mg}^{-1}\right.$ protein) & $875.53 \pm 106.25^{\mathrm{a}}$ & $857.02 \pm 125.35^{\mathrm{a}}$ \\
Trypsin $\left(\mathrm{U} \mathrm{mg}^{-1}\right.$ protein) & $11.19 \pm 0.33^{\mathrm{b}}$ & $29.92 \pm 0.63^{\mathrm{a}}$ \\
Chymotrypsin $\left(\mathrm{U} \mathrm{mg}{ }^{-1}\right.$ protein) & $25.58 \pm 0.73^{\mathrm{a}}$ & $29.49 \pm 2.79^{\mathrm{a}}$ \\
TR:CH ratio & $0.44 \pm 0.01^{\mathrm{b}}$ & $1.03 \pm 0.09^{\mathrm{a}}$ \\
\hline \hline
\end{tabular}

Values (mean \pm SEM) in each row with different superscript notation indicate statistically significant differences between the treatments $(\mathrm{P}<0.05)$

synbiotic (BetaPlus ${ }^{\circledR}+\mathrm{IMO}$ ) on the serum antioxidant responses of Caspian brown trout are shown in Table 3. The serum SOD activity was significantly higher in the fed fish the synbiotic than in the control fed fish $(\mathrm{P}<$ 0.05). However, the serum CAT was non-significantly higher in the synbiotic group than in the control group $(\mathrm{P}>0.05)$. The analysis of the intestinal enzymes activity of Caspian brown trout fed the experimental diets is displayed in Table 4. After the seven-week trial period, the gut trypsin activity and trypsin-chymotrypsin ratio (TR:CH) were significantly higher in the fish treated with BetaPlus ${ }^{\circledR}+\mathrm{IMO}(\mathrm{P}<0.05)$. The gut amylase and chymotrypsin activities and the soluble protein concentration were non-significantly higher in the Caspian brown trout fed the synbiotic diet $(\mathrm{P}>0.05)$, while a non-significant decrease of gut lipase activity was observed in the synbiotic treatment $(\mathrm{P}>0.05)$.

\section{Discussion}

Recently, using synbiotics as an alternative to antibiotics by aquatic nutritionists has been expanded to improve the speed and levels of growth, reduce the costs of production, and increase safety against stress and a variety of pathogens in aquaculture farms. Based on our findings (Table 1), the significantly enhanced growth function in Caspian brown trout fingerlings fed the synbiotic (BetaPlus ${ }^{\circledR}+$ IMO) diet could be due to improved efficiency in feed consumption and feed intake compared to the fish fed the control diet. Previous findings in studies that used other synbiotics were similar to the results of the present research and improved growth performances have been reported by Rodriguez-Estrada et al. (2013) in rainbow trout, Oncorhynchus mykiss (Walbaum) fed a combined diet of Enterococcus faecium and mannan oligosaccharide (MOS), and by $\mathrm{Li}$ et al. (2009) in white shrimp (Litopenaeus 
vannamei) fed a diet containing Bacillus OJ and IMO.

The antioxidant defense system of fish might be associated with factors such as feeding behavior, feed consumption, age, and diet type (Martinez-Alvarez et al. 2005). The combined inclusion of BetaPlus ${ }^{\circledR}$ and IMO significantly increased the activity of serum SOD in Caspian brown trout compared with the control group, which can be caused by the effective role of the dietary synbiotic in regulating the balance of the body's free radicals and enhancing antioxidant capacity, which resulted in improved host immunity (Lee et al. 2013). In accordance with our results, Black Amur bream, Megalobrama terminalis (Richardson) fed a combined diet of B. licheniformis and fructooligosaccharide (FOS) revealed significantly increased serum SOD activity (Zhang et al. 2013).

The two key digestive proteases of trypsin and chymotrypsin are effective indicators in the nutritional performance of the fish species. Additionally, the TR:CH ratio can be considered to be an influential indicator of nutritional performance in fish (Cara et al. 2007). In our study, significant improvements in gut trypsin activity, the TR: $\mathrm{CH}$ ratio, and a marginal increase in gut chymotrypsin activity using the combined inclusion of BetaPlus ${ }^{\circledR}$ and IMO in the diet can enhance feed digestion and absorption, and, as a result, the growth efficiency of Caspian brown trout fingerlings, as was observed in the present research. Similarly, the inclusion of the synbiotic Biomin ${ }^{\circledR}$ IMBO at a level of $1 \mathrm{~g} \mathrm{~kg}^{-1}$ to the diet of common carp, Cyprinus carpio L., fingerlings showed the highest significant activity of trypsin and chymotrypsin enzymes compared to the control fish (Ghasempour Dehaghani et al. 2015).

It is evident that the value of product in aquaculture is associated with the amounts of body protein and lipid; thus, many previous nutritional studies have focused on these two carcass factors by enhancing the nutrient intake and consequently inducing better growth performance and carcass quality. Based on our data, the crude protein and lipid contents of the carcass were significantly affected by the dietary synbiotic (BetaPlus ${ }^{\circledR}+$ IMO). In contrast to our results, carcass composition was not modified in rainbow trout fed a dietary mixture of $E$. faecalis and MOS (Rodriguez-Estrada et al. 2013), nor in Black Amur bream following the combined incorporation of B. licheniformis and FOS in the feed (Zhang et al. 2015). Similar to the achievements of this study, the carcass crude protein and lipid were significantly increased and decreased, respectively, in Japanese flounder, Paralichthys olivaceus (Temminck \& Schlegel) following combined supplementation with B. clausii and FOS, MOS (Ye et al. 2011). Grisdale-Helland et al. (2013) states that the body reduced lipid is often accompanied by an optimal balance of amino acids, which can usually be associated with reduced catabolism of amino acids, and, thus, improved muscle protein synthesis. This phenomenon explains the significant increase and decrease of carcass protein and lipid, respectively, effected by the dietary combination of BetaPlus ${ }^{\circledR}$ and IMO in the diet of Caspian brown trout fingerlings, which is mentioned in the results. The role of minerals in the skeletal structure and in regulating osmotic pressure in the fish body, and especially proteinization processes, is of particular importance during the early stages of fish growth (Lovell 1989). In the present study, the highest amount of carcass ash in the synbiotic treatment indicated an increase in carcass minerals compared to the control group, which was probably due to the effect of the IMO combined with BetaPlus ${ }^{\circledR}$ in increasing the concentration of short-chain fatty acids and, as a result, increasing the absorption of bivalent cations such as calcium, magnesium, zinc, and iron from the gut of the Caspian brown trout fingerlings. This potential effect has been proven for prebiotics (Delzenne and Roberfroid 1994). As non-digestible carbohydrates, or fiber, the presence of IMO in the synbiotic composition applied in the present study also partly explains the carcass composition tendency of the fish given the synbiotic treatment to having significantly increased crude fiber versus significantly reduced carcass carbohydrate in comparison to the control group. Changes in protein density and amino acids are good indicators of changes in the amount of dry matter; thus, increasing carcass protein can lead to reductions in the amount of dry matter in the body (Aletor 
et al. 2000); this is also apparent in the carcasses of the Caspian brown trout fingerlings fed the synbiotic diet in the current study.

To conclude, BetaPlus ${ }^{\circledR}$ containing two strains of Bacillus bacteria, including $B$. subtilis and $B$. licheniformis at $0.1 \%$, in combination with IMO at $0.2 \%$ effectively improved the growth indices, serum antioxidant defense with an emphasis on SOD activity, digestive proteases efficiency (gut trypsin activity and TR:CH ratio), as well as the muscle protein and ash of Caspian brown trout, S. trutta caspius, fingerlings. Thus, the synbiotic (BetaPlus ${ }^{\circledR}+$ IMO) is a suitable candidate for enhancing the quality and commercial value of the final product of Caspian brown trout and even other salmonids in aquaculture.

Acknowledgments. We are grateful to the CFRC (Dohezar, Tonekabon, Mazandaran province, Iran) for providing the fish and their help during the trial. We also thank Dr. N. Miraalami, Life Science Laboratory (Rasht, Guilan province, Iran) administrator, for supplying us with the probiotic BetaPlus ${ }^{\circledR}$ and the prebiotic IMO and for his kind assistance during the study. We are grateful to the CFRC (Dohezar, Tonekabon, Mazandaran province, Iran) for their help during the trial.

Author contributions. M.A. designed the study, performed the study, and wrote the manuscript; A.S. supervised the study and analyzed the data; M.M. supervised the study and assisted in conducting the study; A.H.B.S and M.E.J.Z. were the study advisors.

\section{References}

Adebola O.O., Corcoran O., Morgan W.A. 2014 - Synbiotics: the impact of potential prebiotics inulin, lactulose and lactobionic acid on the survival and growth of lactobacilli probiotics - J. Funct. Foods 10: 75-84.

Adel M., Safari R., Yeganeh S., Binaii M., Ghiasi M., Ahmadvand S. 2017 - Effect of dietary GroBiotic ${ }^{\circledR}$ A supplementation as a prebiotic on the intestinal microflora, growth performance, haemato - serological parameters, survival rate and body composition in juvenile beluga (Huso huso Linnaeus, 1754) - Aquacult. Nutr. 23: 492-499.
Aftabgard M., Salarzadeh A., Mohseni M., Bahri Shabanipour A.H., Zorriehzahra M.E.J. 2017 - The combined efficiency of dietary isomaltooligosaccharides and Bacillus spp. on the growth, hemato-serological, and intestinal microbiota indices of Caspian brown trout (Salmo trutta caspius Kessler, 1877) - Probiotics Antimicro. Prot. https://doi.org/10.1007/s12602-017-9361-z.

Aletor V.A., Hamid I.I., Nieß E., Pfeffer E. 2000 - Low-protein amino acid-supplemented diets in broiler chickens: effects on performance, carcass characteristics, whole-body composition and efficiencies of nutrient utilization - J Sci. Food Agric. 80: 547-554.

AOAC 1990 - Official methods of analysis of the association of official analytical chemists. Association of Official Analytical Chemists, Arlington, USA.

Bernfeld P. 1955 - Amylases $\alpha$ and $\beta$ - In: Methods in Enzymology (Eds) P. Colowick, N.O. Kaplan, Academic Press: $149-158$.

Bradford M.M. 1976 - A rapid and sensitive method for the quantitation of microgram quantities of protein utilizing the principle of protein-dye binding - Anal. Biochem. 72 (1-2): 248-254.

Cara B., Moyano F.J., Zambonino J.L., Fauvel C. 2007 Trypsin and chymotrypsin as indicators of nutritional status of post-weaned sea bass larvae - J. Fish Biol. 70: 1798-1808.

Coad B.W. 2000 - Criteria for assessing the conservation status of taxa (as applied to Iranian freshwater fishes) Biologia 55: 537-555.

Del Mar E.G., Largman C., Brodrick J.W., Geokas M.C. 1979 - A sensitive new substrate for chymotrypsin - Anal. Biochem. 99: 316-320.

Delzenne N.M., Roberfroid M.R. 1994 - Physiological effects of non-digestible oligosaccharides - LWT - Food Sci. Thechnol. 27: 1-6.

Dorafshan S., Kalbassi M.R., Pourkazemi M., Amiri B.M., Soltan Karimi S. 2008 - Effects of triploidy on the Caspian salmon (Salmo trutta caspius) haematology - Fish Physiol. Biochem. 34: 195-200.

Erlanger B.F., Kokowsky N., Cohen W. 1961 - The preparation and properties of two new chromogenic substrates of trypsin - Arch. Biochem. Biophys. 95: 271-278.

Ghasempour Dehaghani P., Javaheri Baboli M., Taghavi Moghadam A., Ziaei-Nejad S., Pourfarhadi M. 2015 Effect of synbiotic dietary supplementation on survival, growth performance, and digestive enzyme activities of common carp (Cyprinus carpio) fingerlings - Czech J. Anim. Sci. 60: 224-232.

Gibson G., Roberfroid M.B. 1995 - Dietary modulation of the human colonic microbiota: introducing the concept of prebiotics - J. Nutr. 125(6): 1401-1412.

Goth L. 1991 - A simple method for determination of serum catalase activity and revision of reference range - Clin. Chim. Acta, 196: 143-151. 
Gouveia A., Davies S.J. 2000 - Inclusion of an extruded dehulled pea seed meal in diets for juvenile European sea bass (Dicentrarchus labrax) - Aquaculture 182: 183-193.

Grisdale-Helland B., Lemme A., Helland S.J. 2013 Threonine requirement for maintenance and efficiency of utilization for threonine accretion in Atlantic salmon smolts determined using increasing ration levels Aquaculture 372-375: 158-166.

Guzmán-Villanueva L.T., Ascencio-Valle F., Macías-Rodríguez M.E., Tovar-Ramírez D. 2014 Effects of dietary b-1,3/1,6-glucan on the antioxidant and digestive enzyme activities of Pacific red snapper (Lutjanus peru) after exposure to lipopolysaccharides Fish Physiol. Biochem. 40: 827-837.

Hoseinifar S.H., Hoseini S.M., Bagheri D. 2017 - Effects of galactooligosaccharide and Pediococcus acidilactici on antioxidant defence and disease resistance of rainbow trout, Oncorhynchus mykiss - Ann. Anim. Sci. 17: 217-227.

Kaneko T., Yokoyama A., Suzuki M. 1995 - Digestibility characteristics of isomaltooligosaccharides in comparison with several saccharides using the rat jejunum loop method - Biosci. Biotechnol. Biochem. 59: 1190-1194.

Lee J.S., Cheng H., Damte D., Lee S.J., Kim J.C., Rhee M.H., Suh J.W., Park S.C. 2013 - Effects of dietary supplementation of Lactobacillus pentosus PL11 on the growth performance, immune and antioxidant systems of Japanese eel Anguilla japonica challenged with Edwardsiella tarda - Fish Shellfish Immunol. 34: 756-761.

Li J., Tan B., Mai K. 2009 - Dietary probiotic Bacillus OJ and isomaltooligosaccharides influence the intestine microbial populations, immune responses and resistance to white spot syndrome virus in shrimp (Litopenaeus vannamei) - Aquaculture 291: 35-40.

Lovell R.T. 1989 - Nutrition and Feeding of Fish - Van Nostrand Reinhold, New York, USA, 260 p.

Marklund S., Marklund G. 1974 - Involvement of superoxide anion radical in the auto oxidation of pyrogallol and a convenient assay for superoxide dismutase - Eur. J. Biochem. 47: 469-474.

Martinez-Alvarez R.M., Morales A.E., Sanz A. 2005 - Antioxidant defenses in fish: biotic and abiotic factors - Rev. Fish Biol. Fish. 15: 5-88.

Ramos M.A., Weber B., Goncalves J.F., Santos G.A., Rema P., Ozorio R.O.A. 2013 - Dietary probiotic supplementation modulated gut microbiota and improved growth of juvenile rainbow trout (Oncorhynchus mykiss) - Comp. Biochem. Physiol. Part A Mol. Integr. Physiol. 166: 302-307.

Ringø E., Olsen R.E., Gifstad T.Ø., Dalmo R.A., Amlund H., Hemre G.I., Bakke A.M. 2010 - Prebiotics in aquaculture: a review - Aquacult. Nutr. 16: 117-136.

Rodriguez-Estrada U., Satoh S., Haga Y., Fushimi H., Sweetman J. 2013 - Effects of inactivated Enterococcus faecalis and mannan oligosaccharides and their combination on growth, immunity, and disease protection in rainbow trout - North Am. J. Aquacult. 75: 416-428.

Sotoudeh E., Abedian Kenari A., Habibi Rezaei M. 2011 Growth response, body composition and fatty acid profile of Caspian brown trout (Salmo trutta caspius) juvenile fed diets containing different levels of soybean phosphatidylcholine - Aquacult. Int. 19: 611-623.

Van Doan H., Doolgindachbaporn S., Suksri A. 2016 - Effect of Lactobacillus plantarum and Jerusalem artichoke (Helianthus tuberosus) on growth performance, immunity, and disease resistance of Pangasius catfish (Pangasius bocourti, Sauvage 1880) - Aquacult. Nutr. 22: 444-456.

Yanbo W., Zirong X. 2006 - Effect of probiotics for common carp (Cyprinus carpio) based on growth performance and digestive enzyme activities - Anim. Feed Sci. Technol. 127: 283-292.

Ye J.D., Wang K., Li F.D., Sun Y.Z. 2011 - Single or combined effects of fructo- and mannan oligosaccharide supplements and Bacillus clausii on the growth, feed utilization, body composition, digestive enzyme activity, innate immune response and lipid metabolism of the Japanese flounder Paralichthys olivaceus - Aquacult. Nutr. 17: e902-e911.

Zhang C.N., Li X.F., Xu W.N., Jiang G.Z., Lu K.L., Wang L.N. 2013 - Combined effects of dietary fructooligosaccharide supplementation and Bacillus licheniformis on innate immunity, antioxidant capability and disease resistance of triangular bream (Megalobrama terminalis) - Fish Shellfish Immunol. 35: 1380-1386.

Zhang C.N., Li X.F., Xu W.N., Zhang D.D., Lu K.L., Wang L.N., Tian H.Y., Liu W.B. 2015 - Combined effects of dietary fructooligosaccharide and Bacillus licheniformis on growth performance, body composition, intestinal enzymes activities and gut histology of triangular bream (Megalobrama terminalis) - Aquacult. Nutr. 21: 755-766. 